\title{
ZBAWCZA MISJA DUCHA ŚWIĘTEGO WEDŁUG PROGRAMU DUSZPASTERSKIEGO DLA KOŚCIOŁA W POLSCE NA LATA 2017-2019
}

Dwuletni program duszpasterski dla Kościoła w Polsce na lata 2017-2019 koncentrował się na dwóch hasłach: „Jesteśmy napełnieni Duchem Świętym” (Dz 2,4)1 - hasło roku 2017-2018, oraz: „W mocy Bożego Ducha"2 - hasło roku 2018-2019. W czasach starotestamentalnych Duch jawił się jako moc Boża, ${ }^{3}$ jako działająca obecność Boga. W Nowym Testamencie Duch zyskuje wyraźne cechy osoby, jest Osobą-Darem, przy czym „dar Ducha i zadanie dawania świadectwa, przepowiadania i misji są sposobami teraźniejszej obecności Chrystusa". 4

Mając na uwadze powyższe refleksje, w kolejnych paragrafach artykułu dokonamy analizy, zmierzającej do ukazania zbawczej misji Ducha Świętego według przytoczonego programu. Posłużymy się publikacjami Sekretariatu Komisji Duszpasterskiej Konferencji Episkopatu Polski. ${ }^{5}$ Mimo że w publikacjach tych nie odnajdziemy

1 Por. J. Bartoszek, R. Chromy, K. Piechaczek (red.), Jesteśmy napetnieni Duchem Świętym. Program duszpasterski Kościoła w Polsce na rok 2017/2018. Zeszyt teologiczno-pastoralny, Katowice 2017.

2 Por. ciż (red.), W mocy Bożego Ducha. Program duszpasterski Kościoła w Polsce na rok 2018/2019. Zeszyt teologiczno-pastoralny, Katowice 2018.

3 Por. W. Chrostowski, Biblijna nauka o Duchu Świętym, w: J. Bartoszek, R. Chromy, K. Piechaczek (red.), Jesteśmy napełnieni Duchem Świętym, s. 51.

4 Por. J. Ratzinger/Benedykt XVI, Opera Omnia, t. VI, cz. 2: Jezus z Nazaretu. Studia o chrystologii, wyd. KUL, Lublin 2015, s. 788.

5 Program duszpasterski na lata 2017-2019 jest uwzględniony w pięciu zeszytach: maryjnym, liturgicznym, katechetycznym, homiletycznym i teologiczno-pastoralnym. 
systematycznego ani w pełni zadowalającego wykładu pneumatologii, skorzystamy z kilku artykułów, zamieszczonych w materiałach programu, które potraktujemy jako literaturę źródłową. W celu całościowego ujęcia zagadnienia posłużymy się również literaturą przedmiotu, nie przywołaną wprost w treści artykułów, lecz nadmienioną w odnośnikach. Nie pominiemy ponadto ukazania problemów mniej wyeksponowanych w programie.

\section{Duch Święty w zbawczym posłannictwie Jezusa Chrystusa}

Wiara w Boskość i osobowość Ducha Świętego jest istotną prawdą trynitologii i stoi na straży fundamentalnych prawideł soteriologii, których znaczenie dostrzegamy dziś z nową ostrością. Nie brakuje bowiem zarówno poglądów neoariańksich, kwestionujących Bóstwo Chrystusa, na co w Jubileuszowym Roku 2000 zwracał uwagę kard. Joseph Ratzinger w deklaracji Dominus Iesus, jak i kwestionowania Bóstwa Ducha Świętego, bez którego zbawienie jest niemożliwe.

Przywołując tajemnicę zwiastowania, program duszpasterski akcentuje, że dla Jezusa jest ona Pięćdziesiątnicą, która potwierdza, że „znamię tożsamości i wiarygodności Mesjasza stanowi trwała obecność Ducha Świętego". "W Waśnie dlatego Chrystus, na którym spoczął sam Duch Święty, siedmioraki w darach, powinien być uznany za typowego charyzmatyka i to charyzmatyka najwybitniejszego w dziejach, bo zespalającego w sobie całą pełnię Ducha. Ukazując Boską Osobę Chrystusa, nie można więc pomijać wytycznych prawowiernej pneumatologii, ponieważ prowadzi to do nieobiektywnej interpretacji Jego posłannictwa. Przede wszystkim jednak niezbędne jest odniesienie do dogmatu trynitarnego, gdyż tajemnica Trójcy

Jak wynika już z samych tytułów poszczególnych zeszytów, do teologii odnoszą się jedynie dwa zeszyty teologiczno-pastoralne. W artykule odnosimy się więc jedynie do zawartych w nich treści pneumatologicznych, nie wchodząc w inne szczegóły schematu programu duszpasterskiego. Uwzględnione zostaną jednak publikacje teologiczne, zbieżne z tytułem artykułu, które wyraźnie potwierdzają doniosłość interesującej nas problematyki.

6 W. Chrostowski, Biblijna nauka o Duchu Świętym, s. 53. 
Świętej oświeca wszystkie tajemnice wiary (por. KKK 234), ukazując wpierw, na czym polega obecność Ducha w życiu i misji Chrystusa, aby następnie ukazać ją w Jego wyznawcach. Szkoda, że w programie duszpasterskim brakuje oddzielnego artykułu o prymacie Trójcy Świętej.

Na prymat Trójcy Świętej w misji Jezusa wskazują wszyscy ewangeliści, począwszy od Marka, od którego są zależni Mateusz i Łukasz. Ukazując teofanię trynitarną, potwierdzają oni, że podczas chrztu w Jordanie Jezus, umiłowany Syn Ojca Przedwiecznego, jawi się jako Ten, który będzie chrzcił „w Duchu Świętym” (por. Mk 1,8; Mt 3,11-12; Łk 3,16). ${ }^{7}$ Podobnie uczy Jan, który m.in. dlatego bywa uznawany za jednego z synoptyków, ${ }^{8}$ przy czym w Ewangelii Jana ,pojawia się element istotnie nowy, który przybiera postać jakby nowego rytuału chrystologicznego: "Chrzczący Duchem Świętym»". 9

Warto dostrzec subtelną różnicę: według Marka i Jana Jezus będzie chrzcił Duchem Świętym, natomiast według Mateusza i Łukasza - „Duchem Świętym i ogniem”. Łukasz w 3,17, a Mateusz w 3,12 czynią aluzję do sądu, w którym ogień będzie narzędziem kary. Odniesienia nowotestamentowe wyraźnie wskazują, że namaszczenie Mesjasza Duchem Świętym potwierdzają fakty z Jego publicznej działalności, o czym świadczy poddanie się kuszeniu na pustyni (por. Mk 1,13) i wyrzucanie złych duchów (por. Mt 12,28). Taka więź Syna Bożego z Duchem Świętym w czasie Jego ziemskiego posłannictwa osiągnęła punkt kulminacyjny w paschalnej tajemnicy Chrystusa, a zwłaszcza w Jego zmartwychwstaniu. Dla św. Jana godzina Paschy jest jednocześnie ,godziną” Jezusa i ,godziną Ducha”, jako że dotąd Duch ,nie był jeszcze dany” (J 7,39). Ponadto Jan używa zupełnie nowej formuły: „oddać ducha” (paredoken to

7 Por. J.-B. Alsac, Łaska chrztu w Duchu Świętym, tłum. M. Szewc-Osiecka, Kraków 2018.

8 Por. B. Adamczewski, Czy Jan byt czwartym synoptykiem? WST 31(2018) nr 1, s. 79-93.

9 A. Siemieniewski, M. Kiwka, Boży płomień. Chrzest w Duchu Świętym, wyd. Wrocławskiej Księgarni Archidiecezjalnej, Wrocław 2017, s. 20. 
pneuma: J 19,30), co obok znaczenia ,umrzeć = oddać ducha”, ma znaczenie o wiele głębsze: ,przekazał Ducha”10 na odpuszczenie grzechów oraz jednoczenie wiernych we wspólnocie, która ma świadczyć o Chrystusowym zmartwychwstaniu (zob. Dz 2,33). ${ }^{11}$ „,To, co Ojciec uczynił dla nas w Chrystusie, w mocy Ducha jest dokonywane i znajduje spełnienie". ${ }^{12}$ Duch Święty, który przemienił ciało Jezusa Chrystusa, kiedy Ojciec wskrzesił Go z martwych por. (Rz 8, 11), przyoblecze w Chrystusową chwałę nasze ciała.

Podzielając powyższe myśli, należy zauważyć, że do dzisiaj zbyt jednostronnie pojmuje się chrystologię, ograniczając ją do ekonomii wcielonego Syna Bożego, zaś Duchowi Świętemu przypisuje się jedynie rolę wtórną i niejako podporządkowaną. Tymczasem dopiero ukazanie roli Ducha Świętego charakteryzuje adekwatnie wszechobejmującą działalność Jezusa, która jest dla wiernych „chrztem w Duchu Świętym”, a także zapowiada - spełnione już w Jezusie obiecane przez proroków (Ez 36,26-29; J1 3,1-5) wylanie Ducha, wzbogacające umysł ludzki słowem poznania (Logos gnōseōs - 1Kor 1,9). Nikt z wzbogaconych takim darem nie może jednak w żadnej mierze zaprzeczyć, że pełnia poznania jest tylko w trójjedynym Bogu, „W którym skryte są wszystkie skarby mądrości i poznania” (por. Kol 2,3) oraz że „cała Pełnia: Bóstwo, na sposób ciała” (Kol 2,9) mieszka tylko w Chrystusie.

\section{Oddziaływanie mocy Ducha Świętego we wnętrzu człowieka}

Według św. Atanazego, mającego znaczący wpływ na Credo Nicejskie podczas kryzysu ariańskiego (325 r.), Duch Święty, który kiedyś ukształtował Logos, czyli Słowo Boże w łonie Dziewicy,

10 Por Y. Congar, Wierzę w Ducha Świętego, t. I, Warszawa 1997, s. 95.

1 Por. A. Malina, Słowo, które przekonuje (1Tes 1,5). Biblia o mocnych w Duchu Świętym i ich dziełach, w: J. Bartoszek, R. Chromy, K. Piechaczek (red.), W mocy Bożego Ducha, s. 35-47.

12 Por. A. Czaja, Od przyjęcia darów Ducha Świętego do apostolatu i misji. Wielkie możliwości i zadania, w: tamże, s. 51. 
teraz kształtuje Go we wnętrzu człowieka, oświecając jego umysł i uświęcając w działaniu. ${ }^{13}$ Duch Święty, wychodząc od Boga jako Osoba-Dar, sprawia, że rodzi się „człowiek duchowy”, realizujący w pełni swoje człowieczeństwo na drodze świętości, do której jest powołany. ${ }^{14}$ Uświęcająca, czyli zbawcza funkcja duchowości chrześcijańskiej polega na wejściu w relację osobową - „z Kimś”, z Osobą Boską, a nie w relację rzeczową - „z czymś”, nawet jeśli to „coś” miałoby źródło w działaniu Boga.

Boska Osoba Ducha przekonuje wierzących, że na skutek pokus będą narażeni na uleganie „tajemnicy bezbożności” (KKK 675), która jest przyczyną bezprawia (mysterion tes anomias) - co św. Hieronim przełożył na łacinę jako mysterium iniquitatis. Należy tu wskazać na „zatwardziałość serca”, o której mówi Pismo Święte (por. Ps 81,13; Jr 7,24; Mk 3,5), a której „odpowiada poniekąd w naszej epoce utrata poczucia grzechu", "będąca jaką́s formą lub owocem negacji Boga", ${ }^{16}$ a więc bezbożności. Bezbożność zaś jest cechą władcy tego świata, który został zwyciężony w paschalnej tajemnicy Chrystusa. ${ }^{17}$ Aby mieć udział w tym zwycięstwie, trzeba - jak uczy św. Jan Paweł II w encyklice Veritatis splendor - uznać swoją grzeszność, otwierając serce na zbawczy Dar Boga oraz mieć odwagę badać siebie, szukając odpowiedzi na pytania: „Co powinienem czynić? Jak odróżniać dobro od zła?”. ${ }^{8}$ Jak postępować w świetle blasku prawdy, na który wskazują pierwsze słowa i tytuł przywołanej encykliki.

Dochodzi tu do głosu, dokonywane mocą Ducha Świętego, oczyszczenie wnętrza człowieka, a więc przemiana, która grzesznika czyni

13 Por. Atanazy Aleksandryjski, Epistula ad Serapionem 1,19. Epistula Ad Serapionem 11,24 - PG 26,586.

14 Por. Franciszek, Adhortacja apostolska Gaudete et exsultate. O powołaniu do świętości w świecie współczesnym, nr 3-34.

15 Jan Paweł II, Encyklika Dominum et Vivificantem, nr 47.

16 Tenże, Adhortacja apostolska Reconciliatio et Poenitentia, nr 18; por. J. Warzeszak, Duch Święty a grzech. Przyczynek do hamartiologii pneumatologicznej, WST 22(2009) nr 2, s. 151-190.

17 Por. Jan Paweł II, Encyklika Dominum et Vivificantem, nr 27-29.

18 Tenże, Encyklika Veritatis splendor, nr 2. 
„,nowym stworzeniem”: przyjacielem Boga i świętym. Siedmioraki w darach Duch Święty sprawia, że współczesna charytologia, nie rezygnując z nauki o łasce jako rzeczywistości stworzonej, dobitnie podkreśla jej osobowy wymiar, polegający na spotkaniu przez człowieka Osób Trójcy Świętej, a zwłaszcza na działającej w nas - na płaszczyźnie wolności i obdarowania - Trzeciej Osoby Boskiej, która jest Darem trynitarnej miłości Ojca i Syna. ${ }^{19} \mathrm{~W}$ programie duszpasterskim sprawa ta odzwierciedla się w aspekcie duszpasterskim. Szkoda jednak, że nie uwyraźniono jej wystarczająco w ujęciu ściśle pneumatologicznym, który domaga się ścisłej syntezy z innymi traktatami teologii dogmatycznej. ${ }^{20}$ Pozwoliłoby to dobitnie stwierdzić, że „Duch Święty jest współmiłującym z Ojcem i współmiłowanym z Synem. Zachowując swoją odrębność osobową, jest darem Miłości, który sprawia, że każda Osoba Boska jest darem dla drugiej, na wzór Dawcy aktualizuje Miłość, w której znajdują upodobanie wszyscy Trzej". ${ }^{21}$

Najbardziej oczywistą w tym względzie prawdą teologiczną jest nauka o chrzcie i bierzmowaniu jako drodze otrzymywania Ducha Świętego, który wraz z Ojcem i Synem zamieszkują w duszy wierzącego jak w świątyni, zaszczepiając w niej zadatek życia wiecznego. Ponadto ,chrzest w wodzie i Duch wprowadzają chrześcijanina do wspólnoty Ciała, które jest Ciałem Chrystusa (1Kor 12,12-13)". ${ }^{22}$

19 Por. (zbior.), Duch, który umacnia miłość. Siedem darów Ducha Świętego, wyd. „M”, Kraków 2017; J. Brusiło, Duszpasterskie aspekty przyjęcia darów Ducha Świętego, w: J. Bartoszek, R. Chromy, K. Piechaczek (red.), Jesteśmy napetnieni Duchem Świętym, s. 99-111.

20 Warto zauważyć, że publikujących na temat Ducha Świętego na początku trzeciego tysiąclecia jest wyjątkowo wielu. Niemal wszyscy odwołują się do dwóch wybitnych teologów XX w.: Heriberta Mühlena (1927-2006), którego najważniejszą pozycją pneumatologiczną jest Una Mystica Persona (w Polsce przybliżył ją bp Andrzej Czaja) i Yves'a Congara (1904-1995), którego trylogia pneumatologiczna pt. Wierzę w Ducha Świętego jest powszechnie znana dzięki jej wersji polskojęzycznej.

21 W. Hryniewicz, Człowiek w mocy Ducha Świętego. Zarys pneumatologii Ojców Wschodnich, Znak 29(1977) nr 7-8, s. 775-793.

22 Y. Congar, Wierzę w Ducha Świętego, t. III, Warszawa 1996, s. 264; por. Jan Paweł II, Encyklika Dominum et Vivificantem, nr 48. 
Odwołując się do tekstów biblijnych, można tu wymienić: namaszczenie Duchem Świętym (Iz 61,1; Łk 4,8; Dz 10,38; 2Kor 1,21 nn.; 1J 20,27); wylanie Ducha Świętego (Iz 32,15; Ez 39,29; Za 12,10; Dz 2,16; 10,45; Rz 5,5; Tt 3,5nn.); chrzest w Duchu Świętym (Iz 1,16; 44,3nn.; Ez 36,25nn.; Mk 1,8; Dz 1,5; 11,16), który jawi się obecnie jako cel grup odnowy charyzmatycznej. ${ }^{23}$ Przywołane teksty świadczą, że człowiek obdarzony darem Ducha Świętego przeżywa osobiście wydarzenie Pięćdziesiątnicy, które św. Jan Paweł II, w katechezie środowej z 6 września 1989 r., ujmuje w kategoriach „chrztu w Duchu Świętym” i wyjaśnia, że „,chrzcić w Duchu Świętym znaczy odradzać ludzkość mocą Ducha Świętego". ${ }^{24}$ Odradzanie takie nie jest, oczywiście, zarezerwowane wyłącznie dla grup odnowy.

Warto dodać, że człowiek, który urzeczywistnia zamierzoną przez Boga doskonałość przez przyjęcie Ducha Świętego oraz wewnętrzne otwarcie na Jego Osobę, obecność i moc, jest na ziemi jedynym obrazem Ducha. Trafnie więc twierdzi się, że Ducha Świętego objawia światu człowiek do głębi Nim przesiąknięty, najściślej z Nim zespolony oraz tak uświęcony i uduchowiony, że promieniujący i przeświecający niejako Duchem Świętym. ${ }^{25}$ Takim człowiekiem jest w całej pełni Najświętsza Maryja Panna, którą św. Jan Paweł II nakazuje „kontemplować i naśladować przede wszystkim jako Niewiastę posłuszną głosowi Ducha Świętego, jako Niewiastę, która milczy i słucha, która potrafiła jak Abraham przyjąć wolę Bożą, wierząc wbrew nadziei (por. Rz 4,18)" ${ }^{26}$

Należy zauważyć, że w interesującym nas programie duszpasterskim brakuje teologicznego omówienia istotnej prawdy, która pozwala wykazać, że „Maryja jako widzialne ucieleśnienie Ducha Świętego, a więc jako osoba Nim przeniknięta i jakby przejrzysta

23 Por. A. Siemieniewski, M. Kiwka, Boży płomień. Chrzest w Duchu Świętym.

24 Jan Paweł II, Wierzę w Ducha Świętego, Pana i Ożywiciela, Vatican 1992, S. 75.

25 Por. L. Balter, Pneumahagijny wymiar tajemnicy zbawienia, AK 96/1981, s. 182-193.

26 Jan Paweł II, List apostolski Tertio millenio adveniente, $\mathrm{nr} 48$. 
dla Niego, stanowi najpierw niedościgły wzór właściwie pojętej czci Ducha Świętego: to Ona Go przyjęła, stała się Jego sanktuarium i pozwoliła Mu działać w sobie w typowy dla Niego sposób uduchowiania i uświęcania". ${ }^{27}$ W tym kontekście błędne jest przeciwstawianie sobie życia w Duchu i życia na wzór Matki, która przecież dobrowolnie przyjęła dar Ducha Świętego jako Kontynuatora pośredniczącej i zbawczej misji Chrystusa, w której najpełniej uczestniczy od momentu wcielenia. Przyzwolenie udzielone przez Maryję na przyjście Zbawiciela jest więc nie tylko fizycznym poczęciem dziecka, lecz także ściśle teologalnym aktem wiary. Maryja została Matką Boga przez „tak” - fiat swojej wiary. Dzięki aktualizacji cudu dziewiczego poczęcia ex fide et Spiritu Sancto, ${ }^{28}$ Maryja jawi się jako doskonała ikona wiary, która jest dla pielgrzymującego ludu Bożego znakiem niezawodnej nadziei i pociechy.

Na wzór Maryi, dar Ducha, przetwarzający i odnawiający duchowe wnętrze osoby ludzkiej, rzeczywiście kształtuje Chrystusa. Współbrzmi to ze słowami Benedykta XVI, skierowanymi do młodzieży z okazji XXIII Światowych Dni Młodzieży w Sydney (2008 r.): „Duch Święty oświeca, objawiając Chrystusa ukrzyżowanego i zmartwychwstałego, wskazuje drogę do najpełniejszego upodobnienia się do Niego, aby być «wyrazem i narzędziem miłości, która od Niego pochodzi». ${ }^{29}$ Kto pozwala się prowadzić Duchowi Świętemu, w pełni rozumie, że autentycznym świadkiem Chrystusa można być tylko wtedy, kiedy pozwoli się prowadzić Duchowi Świętemu, który jest «głównym podmiotem ewangelizacji» ${ }^{30}$ i głównym sprawcą misji”. ${ }^{31}$

27 L. Balter, Duch Święty w tajemnicy Maryi i Kościoła, w: J. S. Gajek, K. Pek (red.), Matka Jezusa pośród pielgrzymującego Kościoła, Theotokos 4, Warszawa 1993, s. 256.

28 Por. M. Kowalczyk, Poczęcie Chrystusa „przez wiarę”, Salvatoris Mater 2(2000) nr 2, s. 105-114.

29 Benedykt XVI, Encyklika Deus caritas est, nr 33.

30 Paweł VI, Encyklika Evangelii nuntiandi, nr 75.

31 Benedykt XVI, Orędzie Ojca Świętego Benedykta XVI z okazji XXIII Światowych Dni Młodzieży - Sydney 2008, nr 7; por. Jan Paweł II, Encyklika Redemptoris 


\section{Misja Ducha we wspólnocie ludu Bożego}

Zbawcze udzielanie się Ducha Świętego całemu ludowi i Jego stałe zamieszkiwanie we wspólnocie Kościoła przejawia się konkretnie w rzeczywistości sakramentalnej, z Eucharystią na czele, która - w rozumieniu posoborowym - jest najwyższym wyrazem kultu. ${ }^{32}$ Dzięki obecności Ducha kult sakramentalny, oddawany Bogu w liturgii Kościoła, ikonie Ciała Chrystusa, ogarnia całą wspólnotę eklezjalną, zamieniając wewnętrzny nieurodzaj dusz w urodzajne pola łaski i świętości. ${ }^{33}$

Po II Soborze Watykańskim udzielanie Ducha Świętego zostało wysunięte na pierwszy plan w odnowionych obrzędach sakramentu bierzmowania. Dokonało się to 15 sierpnia 1971 r., na mocy konstytucji apostolskiej św. Pawła VI Divinae consortium naturae. ${ }^{34} \mathrm{Na}$ wiązując do starożytnej formuły bierzmowania, właściwej dla rytu bizantyjskiego, św. Paweł VI podkreślił, że Darem przyjmowanym w bierzmowaniu jest sam Duch Święty, przypominając jednocześnie o wylaniu Ducha, jakie nastąpiło w dniu Pięćdziesiątnicy. W świetle wypowiedzi Ojców II Soboru Watykańskiego, dar Ducha Świętego w bierzmowaniu jeszcze mocniej zobowiązuje chrześcijan do zaangażowania się w budowanie wspólnoty (Communio) Kościoła i w rozszerzanie wiary oraz w jej obronę. ${ }^{35} \mathrm{Z}$ nauki Soboru wynika wyraźnie,

missio. O stałej aktualności posłania misyjnego, nr 21. W programie duszpasterskim tematykę tę omawia bp Andrzej Czaja w drugiej części cytowanego artykułu.

32 Por. J. Buczek, Pneumatologia sakramentalna w nauczaniu Jana Pawła II, Resovia Sacra. Studia Teologiczno-Filozoficzne Diecezji Rzeszowskiej 13/2006, s. 49-77.

33 Por. B. Nadolski, Duch Święty w liturgii, Communio 8(1988) nr 1, s. 104-113; B. Adamczewski, Kościót jako ikona Ciała Chrystusa w Pierwszym Liście do Koryntian, Verbum Vitae 6/2004, s. 162-163.

34 Paweł VI, Konstytucja apostolska Divinae consortium naturae, AAS 63/1971, s. 657-664; D. Zimoń, Odnowiona liturgia sakramentu bierzmowania, Śląskie Studia Historyczno-Teologiczne 8/1975, s. 285-292.

35 Por. KK, nr 11, 49; A. Czaja, Kościół jako komunia w Duchu Świętym. Koncepcja Józefa Kardynała Ratzingera, w: J. Cichoń (red.), Ratio et revelatio. Z refleksji filozoficzno-teologicznych, Opole 1998, s. 351-368. 
że jednym z istotnych elementów egzystencji chrześcijańskiej jest apostolstwo: „Wszczepieni bowiem przez chrzest w Ciało Mistyczne Chrystusa, utwierdzeni mocą Ducha Świętego w bierzmowaniu (...) dostępują poświęcenia na królewskie kapłaństwo i święty naród". ${ }^{36}$ Do spełnienia tego apostolstwa Duch Święty udziela wiernym także innych, szczególnych darów.

Tymi szczególnymi, niezasłużonymi darami Ducha Świętego, udzielanymi dla dobra, czyli budowania Kościoła, są z pewnością charyzmaty (od gr. charizesthai - „obdarowywać”). ${ }^{37}$ Jest to zupełnie zrozumiałe, gdyż słowo „charyzmat” stosuje się w szerszym znaczeniu do wszystkich darów udzielanych przez Boga, a więc także do łask sakramentalnych, przy czym dary charyzmatyczne dotyczą określonych faktów i osób. Yves Congar zauważa, że według św. Pawła wszyscy wyznawcy Chrystusa są charyzmatykami, bowiem „wszyscy są powołani do tego, by wykorzystywać otrzymane dary dla wspólnego dobra". ${ }^{38}$ Należy się więc wystrzegać niebezpieczeństwa sprowadzania charyzmatów do pewnych tylko, niezwykłych czy też wyjątkowych przejawów.

Niestety, obecnie nasila się niebezpieczeństwo nadmiernego przywiązywania wagi do uczuciowego traktowania charyzmatów, a więc przesadnej troski o „spektakularność” i ,nadzwyczajność”. Dotyczy to zwłaszcza „charyzmatycznej” modlitwy i mówienia językami, proroctwa czy daru uzdrawiania. Bez wątpienia takie charyzmaty bywają przeżywane na płaszczyźnie psychologicznej, przez co mogą stanowić zagrożenie dla wiary. Dlatego - jak w programie duszpasterskim pisze bp Jacek Kiciński - „władze Kościoła winny być świadome rzeczywistej nieprzewidywalności charyzmatów wzbudzanych przez Ducha Świętego i oceniać ich znaczenie według reguły

36 DA, nr 3; por. W. Śmigiel, Teologia sakramentu bierzmowania, w: J. Bartoszek, R. Chromy, K. Piechaczek (red.), Jesteśmy napetnieni Duchem Świętym, s. 59-81; A. Schulz, Duch Święty animatorem apostolstwa świeckich, w: J. Bartoszek, R. Chromy, K. Piechaczek (red.), W mocy Bożego Ducha, s. 105-122.

37 Por. M. Kowalczyk, Charyzmat, w: M. Rusecki i in. (red.), Leksykon Teologii Fundamentalnej, wyd. TN KUL - wyd. „M”, Lublin-Kraków 2002, s. 184-188.

38 Y. Congar, Wierzę w Ducha Świętego, t. II, Warszawa 1995, s. 197. 
wiary, w perspektywie budowania Kościoła. Jest to proces, który rozciąga się w czasie i wymaga odpowiednich etapów potwierdzenia poprzez poważne rozeznanie, aż do kościelnego uznania autentyczności charyzmatu". ${ }^{39}$

Jawiące się problemy mogą także wypływać z faktu, że w Polsce nie mamy przestrzeni dla liderów świeckich w Kościele. Nie mają oni swojego przedstawiciela, nie mają gdzie się szkolić. Co prawda „takie inicjatywy są przygotowywane w Zespole ds. Nowej Ewangelizacji Konferencji Episkopatu Polski, ale jeszcze nie funkcjonują". ${ }^{4}$ Może to skutkować jawieniem się tzw. liderów samozwańczych, którzy sprowadzają odnowę charyzmatyczną na manowce. Nie da się zaprzeczyć, że ,niektórzy liderzy religijni przejmują władzę psychiczną nad członkami swoich wspólnot, stosują niedozwolone środki psychomanipulacji, niesprawdzone bądź fałszywe treści religijne przekazują jako pewne i prawdziwe, ograniczają indywidualną wolność swoich wyznawców i zbyt głęboko wpływają na ich osobiste

39 Por. J. Kiciński, Charyzmaty odnawiają Kościól-perspektywy i zagrożenia, w: J. Bartoszek, R. Chromy, K. Piechaczek (red.), Jesteśmy napetnieni Duchem Świętym, s. 90.

40 K. Sobczyk, Wypowiedź na zakończenie międzynarodowego kursu dla liderów wspólnot charyzmatycznych w Krakowie, 23 II 2019 r., https://ekai.pl/krakow-zakonczyl-sie-miedzynarodowy-kurs-dla-liderow-wspolnot-charyzmatycznych/ (dostęp: 24 VII 2019). Warto tu przywołać krytykę nauczania i działalności Marcina Zielińskiego, lidera wspólnoty „Głos Pana” w Skierniewicach, które - jak stwierdził bp Andrzej Czaja - nie są wolne od błędów. „Biskup zaznaczył, że potrzeba dialogu i weryfikowania na bieżąco, co w nauczaniu jest zgodne z depozytem wiary, jednak trzeba to robić poprzez badania teologiczne i formację. Zadeklarował również, że jest gotowy, by spotkać się z (...) Marcinem Zielińskim, a także specjalistami w kontrowersyjnych kwestiach, by rozwiązać tę sprawę ewangelicznie"; zob. Biskup o działalności Marcina Zielińskiego i jego krytykach, https://www.deon.pl/religia/ kosciol-i-swiat/z-zycia-kosciola/art,36265,biskup-o-dzialalnosci-marcina-zielinskie go-i-jego-krytykach.html (dostęp: 12 VII 2019). Jest to krok w dobrą stronę, chociaż należy oczekiwać, że owocem programu duszpasterskiego na lata 2017-2019 będzie rychłe zapewnienie solidnej formacji teologicznej liderów. 
decyzje itd. Tego rodzaju problemy dotyczą także wielu wspólnot charyzmatycznych", ${ }^{4}$

Konkretnie rzecz biorąc, w rozpatrywanym programie duszpasterskim zwraca się uwagę na następujące zagrożenia odnośnie do odnowy Kościoła za przyczyną charyzmatów: pokusę nadmiernej autonomii związanej z indywidualizmem, polegającym na braku posłuszeństwa hierarchii i łączności ze wspólnotą lokalną, pokusę hermetyzmu, która powoduje zamykanie się wspólnot charyzmatycznych we własnym kręgu, co powoduje zagrożenie jedności Kościoła, pokusę subiektywizmu, czyli przedkładania darów osobistych nad wspólnotowe; pokusę sentymentalizmu, która prowadzi do dominacji elementów emocjonalno-przeżyciowych oraz podążania za coraz nowszymi wrażeniami, aż do porzucenia drogi wiary włącznie i wreszcie na pokusę wybiórczości, polegającej na selektywnym podchodzeniu do charyzmatów, którego kryterium jest korzystanie z tego, co ,przyjemne i wygodne”, natomiast rezygnacja z tego, co jest wymagające. ${ }^{42}$ Jawią się tu zagrożenia duchowe, stwarzające niebezpieczeństwo nie tylko dla wiary, lecz także dla samej bytowości człowieka, a więc prowadzące w rzeczywistości do jego destrukcji.

Program duszpasterski nie wspomina wprost o narastającym w Polsce problemie wpływu amerykańskich wspólnot charyzmatycznych na wiernych Kościoła katolickiego, a powinno to być przedmiotem szczególnej troski Kościoła. Chodzi tu szczególnie o grupy biorące swój początek w przebudzeniu zwanym Toronto Blessing (pierwotnie przebudzenie to wywodziło się z pogańskiego kultu

\footnotetext{
${ }^{41}$ A. Kobyliński, Etyczne aspekty współczesnej pentekostalizacji chrześcijaństwa, https://www.deon.pl/religia/wiara-i-spoleczenstwo/art,1428, etyczne-aspekty-wspolczesnej-pentekostalizacji-chrzescijanstwa.html (dostęp: 22 VI 2019); por. tenże, Etyczne aspekty stosowania psychologii w przestrzeni życia religijnego, Rocznik Teologii Katolickiej 14(2015) nr 1, s. 193-211. Ukazane tu problemy wskazują na potrzebę dobrze prowadzonych ruchów odnowy, które w Kościele są niezbędne; por. M. Kowalczyk, Ruchy kościelnej odnowy w ocenie biskupa Josefa Cordes'a, Collectanea Theologica 70 (2000) nr 3, s. 205-211.

42 Por. J. Kiciński, Charyzmaty odnawiają Kościót-perspektywy i zagrożenia, s. 90-93.
} 
kundalini - rodzaj jogi), czyli „domniemanym wylaniu Ducha Świętego na ludzi ze wspólnoty Toronto Airport Christian Fellowship (TACF), wcześniej nazywanej Toronto Airport Vineyard". ${ }^{43}$ Celem ostrzeżenia, a zarazem wezwania do odrębnego potraktowania tego zagrożenia dla zbawczej misji Ducha Świętego w kontekście tzw. Zaśnięcia w Duchu Świętym wystarczy dodać, że „nie ma tu żadnych znamion pochodzenia nadprzyrodzonego, czyli od Boga. Owszem, [fenomen ten] ma znamiona działania sił ponadludzkich. Tym samym wszystko wskazuje na pochodzenie demoniczne". ${ }^{44}$

Nie można tu wykluczyć nawet opętania, które „w teologicznym i głębokim znaczeniu oznacza jakieś oddanie się funkcji szatańskiej, postawę bluźnierstwa przeciwko Bogu, zatwardziałość przeciwko Duchowi Świętemu i swemu sumieniu oraz coś w rodzaju alienacji od dobra moralnego. W każdej z tych postaw musi być, oczywiście, jakiś stopień zgody i winy człowieka. Opętanie zaś, w znaczeniu potocznym i zewnętrznym, to jakieś tajemnicze zawładnięcie przez szatana ciałem człowieka (np. Mk 5,2-9; 9,17-27): obsessio, possessio, insessio, circumsessio. Szatan opanowuje pod pewnym względem swoją ofiarę somatycznie, a wtórnie wpływa i na siły psychiczne człowieka. Ludzkie «ja» wszakże jest uszkodzone tylko częściowo, w głębi zachowuje swoją wolność, sąd i decyzję w sprawach duchowych, choć jakby przyćmione". 45

Z wypaczoną wizją obecności i działania Ducha Świętego mamy dzisiaj do czynienia w zielonoświątkowej wersji chrześcijaństwa, mającego cechy chrześcijaństwa synkretycznego, które - jak zapewniają charyzmatyczni kaznodzieje - miałoby odpowiadać na wszystkie najważniejsze potrzeby człowieka współczesnego. Ksiądz Andrzej Kobyliński, filozof, etyk z Instytutu Filozofii Uniwersytetu

43 M. Remisiewicz, Ł. Malinowski, Czy Toronto Blessing przynosi owoce Ducha Świętego? https:/www.miesiecznikegzorcysta.pl/component/k2/itemlist/ tag/62 (dostęp: 23 VII 2019).

${ }_{44}$ Jak należy teologicznie ocenić tzw. zaśnięcia w Duchu Świętym? https:// teolog katolicki.blogspot.com/2018/03/jak-nalezy-teologicznie-ocenic-tzw.html. (dostęp: 23 VII 2019).

45 Cz. S. Bartnik, Dogmatyka Katolicka, t. 1, Lublin 1999, s. 491. 
Kardynała Stefana Wyszyńskiego w Warszawie, uważa to za przejaw „uzielonoświątkowienia”, które - jako badacz i analityk zjawiska - od 2014 r. uznaje za synonim pentekostalizacji. Stwierdza przy tym, że w ciągu kilkunastu ostatnich lat chrześcijaństwo zielonoświątkowe przybiera formy religijne, w których można się dopatrywać elementów szamanizmu, czyli zespołu wierzeń religijnych i praktyk magicznych, bazujących na zinstytucjonalizowanych, odmiennych stanach świadomości, osiąganych przez specjalnego przedstawiciela społeczności zwanego szamanem, którego cechuje umiejętność wchodzenia w odmienne stany świadomości, a więc osiąganie stanu ekstazy, dzięki której może pośredniczyć między sferami sacrum i profanum, co może nieść różne niebezpieczeństwa, aż do zagrożenia ogólnoświatowym demontażem Kościoła katolickiego. Ksiądz Kobyliński nie waha się włączać w plejadę wymienionych niebezpieczeństw skandalu pedofilii, konkludując swoją argumentację słowami: „Im słabszy Kościół z powodu pedofilii, tym [skwapliwiej] na to spustoszone miejsce wchodzą m.in. wspólnoty zielonoświątkowe". ${ }^{46}$

Z całą pewnością wszystkie te zbyt daleko idące wywody są pozbawione zdrowej samokrytyki i powściągliwości w wyprowadzaniu wniosków. Można je jednak uznać za swoiste przynaglenie do stanowczych wypowiedzi Magisterium Kościoła, w tym popularyzacji dokumentów Konferencji Episkopatu Polski, a także za apel o twórcze publikacje teologów i etyków, opisujące krytycznie wszelkie przejawy manipulowania wiernymi.

Wskazując na przezwyciężenie zagrożeń wynikających z pentekostalizacji, warto przypomnieć, że już ojcowie II Soboru Watykańskiego, ukazując Kościół w perspektywie pneumatologiczno-charyzmatycznej, byli zdania, iż wśród charyzmatów góruje łaska apostołów, których powadze sam Duch poddaje nawet charyzmatyków (1Kor 12,1-11) i że cały Kościół jako Ciało Chrystusa swoją podmiotowość zawdzięcza Duchowi Świętemu oraz Synowi

46 A. Kobyliński, Do Polski od lat przenika szamańskie widzenie religii, https:// polskatimes.pl/ks-prof-andrzej-kobylinski-do-polski-od-lat-przenika-szamanskie-widzenie-religii/ar/c1-14044261/1-2 (dostęp: 29 VII 2019). 
Bożemu, jako praprzyczynom tej podmiotowości. Na tej podstawie można mówić o osobowości korporatywnej Kościoła (por. Rz 5,12-15.18-19), ${ }^{47}$ która jednak - na skutek deformacji - może prowadzić do przekształcania tradycyjnych Kościołów chrześcijańskich w jedną, uniwersalną ,wersję pentekostalną”, prowadzącą niechybnie do wynaturzenia religii chrześcijańskiej. Wynaturzenie takie miał zapewne na uwadze papież Franciszek, kiedy biskupów polskich, zgromadzonych na Wawelu, przestrzegał przed niebezpieczeństwem uduchowienia gnostyckiego, twierdząc, że, jest to duchowość subiektywna, bez Chrystusa. (...). To jest gnostycyzm. (...) znajdować Boga bez Chrystusa, lud bez Kościoła". ${ }^{4}$

Omawiając dosyć szczegółowo zasygnalizowany stan rzeczy, bp Andrzej Czaja wnioskuje, aby poznać i wprowadzić w życie, ogłoszoną w 2000 r. przez Kongregację Nauki Wiary, instrukcję Ardens felicitatis desiderium, na temat modlitwy o uzdrowienie, która ,jest w naszym Kościele prawie nieznana i trudno się dziwić, że Msze św. i nabożeństwa z modlitwą o uzdrowienie są kształtowane na miarę pomysłów, tych którzy je animują". ${ }^{49}$ Nie lepiej jest z recepcją dwóch dekretów KEP: o tzw. spowiedzi furtkowej oraz o ,grzechu i uzdrowieniu międzypokoleniowym”. Szkoda, że program duszpasterski, podejmując w swej treści problematykę ściśle pneumatologiczną, nie odnosi się do takich problemów dosłownie, a ich rozwiązanie należałoby przybliżyć zwłaszcza młodym, nawet jeżeli na to nie oczekują.

Pozostaje jednak ufać, że realizacja programu duszpasterskiego w Polsce, podejmując tematykę wyrażoną słowami: „Duch, który

47 Por. K. Góźdź, Kościół zbawienia, Lublin 2010, s. 123-128.

48 Franciszek, Między kanapa a odwagą. Wszystko, co powiedziat papież podczas Światowych Dni Młodzieży w Krakowie, Wydawnictwo Znak, Kraków 2016, S. 42-43.

49 A. Czaja, Problem pentekostalizacji chrześcijaństwa, Referat wygłoszony na Jasnej Górze 24 stycznia 2017 r., podczas XXVI Sympozjum dla księży rekolekcjonistów, ojców duchownych i spowiedników kapłańskich, http://formacja.diecezja. tarnow.pl/2017/09/problem-pentekostalizacji-chrzescijanstwa-bp-andrzej-czaja/ (dostęp: 13 VI 2019). 
działa przez miłość", ${ }^{50}$ dzięki mobilizacji duszpasterzy i teologów, doprowadzi wiernych do przeżywania chrześcijaństwa jako zbawczego daru Ducha Świętego, Ducha Ojca i Syna, prowadzącego ludzkość do pełni szczęścia, przeżywanego w zjednoczeniu z Bogiem i całą wspólnotą świętych. Trzeba także mieć nadzieję, że dzięki kryteriom rozpoznawania autentyczności charyzmatów spełnią się słowa papieża Franciszka: „Oby Odnowa charyzmatyczna znikła jako taka i oby przemieniła się w łaskę Zielonych Świąt dla całego Kościoła: jeśli rzeka ma być wierna swoim źródłom, powinna zniknąć w oceanie". 51

\section{$* * *$}

Podsumowując, należy zauważyć, że w programie duszpasterskim dla Kościoła w Polsce na lata 2017-2019 trafnie ukazano Ducha (Pneuma) jako boski Dar zbawczy. Zwrócono uwagę, że Bóg i człowiek spotykają się w mocy Ducha Świętego, który umacnia nadzieję, że ostatnim słowem historii poszczególnych osób i wspólnot ludzkich będzie zwycięstwo miłości. Dokona się ono dzięki uwolnieniu, przez udzielenie Ducha, spod prawa grzechu i śmierci (Rz 8,2) i zasadniczemu uświęceniu wnętrza człowieka (1Kor 6,11; Rz 15,16), odczuwającego, że ma udział w życiu wspólnoty osób Boskich. Należy przyznać, że w programie nie pominięto perspektyw i zagrożeń odnowy charyzmatycznej w Kościele. Nie brakuje jednak pewnych uogólnień związanych z charyzmatami. Tymczasem w problematyce określonej słowami ,pneumatologia a charyzmaty” można było wyraźnie uwzględnić „,spoczynek w Duchu Świętym”, Toronto blessing,

50 Por. K. Piechaczek, Założenia, cele, tematyka Programu duszpasterskiego na lata 2017-2019 „,Duch, który działa przez miłośc’”, w: J. Bartoszek, R. Chromy, K. Piechaczek (red.), Jesteśmy napełnieni Duchem Świętym, s. 13-19.

51 Franciszek, Discorso al. movimento del Rinnovamento nello Spirito, 3 lipca 2015, http://w2.vatican.va/content/francesco/it/speeches/2015/july/documents/papa-francesco_20150703_movimento-rinnovamento-spirito.html; por. F. Kleineidam, Dynamische Pneumatologie und Christentum: Heiliger Geist im 21. Jahrhundert, Fischer, Frankfurt am Main 2009. 
a także zagrożenie okultyzmem i homeopatią, w której nie brak tajemnych działań okultystycznych.

W zeszytach teologiczno-pastoralnych programu na uwagę zasługuje ukazanie zbawczego działania Trzeciej Osoby Boskiej, dostrzegalnego w całych dziejach Kościoła i świata. Szkoda jednak, że pominięto, jakie miejsce w relacji do Ducha Świętego zajmuje Najświętsza Maryja Panna, słusznie określana jako Pierwsza charyzmatyczka. Brakuje także zdecydowanego uzasadnienia, że w ostatecznym wydarzeniu dziejów Duch Święty, który aż do końca świata pozostanie Bogiem ukrytym, a więc „Boskim Nieznanym”, doprowadzi nas do całej prawdy (J 16,13), którą realnie spotkamy w Chrystusie, dzięki pełni Jego objawienia w paruzji. ${ }^{52}$ Zagadnienie to, w przekonaniu autora artykułu, powinno być dobitnie odzwierciedlone $\mathrm{W}$ zeszycie teologiczno-pastoralnym programu duszpasterskiego. W związku z pentekostalizacją i łączącymi się z nią kwestiami należałoby się pilnie podjąć naukowej analizy interdyscyplinarnej na temat nowych zjawisk religijnych w Polsce.

Piszący te słowa sugeruje wreszcie, aby na przyszłość zeszyt teologiczny programu duszpasterskiego został opublikowany jako odrębny. Z pewnością zagadnienia związane $\mathrm{z}$ hasłem roku duszpasterskiego mogłyby być wtedy bardziej pogłębione przez duszpasterzy, katechetów czy liderów wspólnot eklezjalnych o wątki czysto teologiczne. W programie na lata 2017-2019 należałoby np. zamieścić osobny artykuł o urzeczywistnianiu królestwa Bożego, którego niezawodnym praźródłem jest zbawczy dar Ducha Świętego. Warto przypominać, że przekonanie o urzeczywistnianiu królestwa Bożego w mocy Ducha towarzyszyło wielu Ojcom Kościoła, którzy zamiast: „Niech przyjdzie Twoje królestwo” (Łk 11,2) mówili: „Niech zstąpi na nas Twój Święty Duch i niech nas oczyści". ${ }^{53}$ Można by również uwzględnić tak ważne aspekty pneumatologii, jak inicjatywy

52 Por. W. Wołyniec, Duch Święty i Kościót w pełni objawienia, Wrocław 2008.

53 Por. Y. Congar, Wierzę w Ducha Świętego, t. 2, s. 89; J. Ratzinger/Benedykt XVI, Opera Omnia, t. VI, cz.1: Jezus z Nazaretu. Studia o chrystologii, s. 169. 
ekumeniczne (por. DE 2), ${ }^{54}$ a także teologiczne docenienie znaczenia dialogu ze współczesną kulturą oraz innymi religiami..$^{55}$

\section{ks. Marian KOWALCZYK SAC}

Słowa kluczowe: Jezus Chrystus; Duch Święty; zbawcza misja; lud Boży; sakramenty

Keywords: Jesus Christ; Holy Spirit; saving mission; people of God; sacraments

\section{The Salvific Mission of the Holy Spirit according to the Pastoral Program for the Church in Poland in 2017-2019}

\section{Summary}

Referring to the pastoral program for the Church in Poland in 20172019, an analysis of the publication of the pastoral committee of the Polish Bishops' Conference for pneumatology was carried out. It was demonstrated that the pastoral program primarily focused on the presence of the Holy Spirit in the life and mission of Jesus Christ in order to show the saving influence of the Spirit on the human being. Also, the accurate presentation of the salvific activity of the Holy Spirit in the community of God's people should be appreciated, especially in the sacraments (with special regard to baptism and confirmation) and in charisms. However, the publication in question results in some overemphasis on the flattering approach to the gifts of the Holy Spirit and the depiction of the discernment of spirits. Moreover, the discussion of temptations and criteria for their discernment, although interesting, is not fully developed in view of the difficulties resulting from

54 Por. Jan Paweł II, Encyklika Ut unum sint, nr 99; tenże, Tertio millennio adveniente, nr 46; J. Bolewski, Nadzieja jedności w Duchu Świętym, w: tenże (red.), Znaki nadziei trzeciego tysiąclecia, Kraków 1999, s. 143-166; M. Hurley, Christian unity. An ecumenical second spring? Dublin 1998; P. Kantyka, Dialog ekumeniczny, w: M. Rusecki (red.), Chrześcijaństwo $w$ dialogu, Studia Nauk Teologicznych PAN, t. 5, wyd. KUL, Lublin 2010, s. 187-198.

55 L. Fic, Dialog międzyreligijny, Pedagogia Christiana 26(2010) nr 2, s. 51-64. 
the inability to precisely distinguish, in charisms, between what man produces and what is the work of the Spirit that surpasses all cognitive abilities. Therefore, apart from pointing out external and internal threats, the program lacks bold references to increasing, far-reaching threats that not only weaken faith, but are also dangerous to the very existence of man, and thus may even lead to his diabolical destruction. Finally, there are few references in the program to such important aspects of pneumatology such as: the role of the Spirit in Mary's maternal mission, the pursuit of Christian unity, interreligious and intercultural dialogue, and the realization of the kingdom of God until its final fulfilment in the Parousia.

\section{Bibliografia}

\section{Dokumenty Magisterium Kościoła}

Baron A., Pietras H. (oprac.), Dokumenty Soborów Powszechnych, t. I: 325-787, wyd. WAM, Kraków 2001.

Benedykt XVI, Encyklika Deus caritas est, Rzym 2005.

Benedykt XVI, Encyklika Spe salvi, Rzym 2007.

Benedykt XVI, Orędzie Ojca Świętego Benedykta XVI z okazji XXIII Światowych Dni Młodzieży - Sydney 2008, Lorenzago, 20 lipca 2007.

Dokumenty Soboru Watykańskiego II, wyd. Pallottinum, Poznań 2008.

Franciszek, Discorso al. movimento del Rinnovamento nello Spirito, 3 lipca 2015, http://w2.vatican.va/content/francesco/it/speeches/2015/july/documents/papa-francesco_20150703_movimento-rinnovamento-spirito.html.

Franciszek, Między kanapa a odwagą. Wszystko, co powiedziat papiez podczas Światowych Dni Młodzieży w Krakowie, Wyd. Znak, Kraków 2016.

Franciszek, Adhortacja apostolska Gaudete et exsultate. O powołaniu do świętości w świecie wspótczesnym, Rzym 2018.

Jan Paweł II, Encyklika Dominum et Vivificantem, O Duchu Świętym w życiu Kościoła i świata, Rzym 1986.

Jan Paweł II, Adhortacja apostolska Reconciliatio et Poenitentia, Rzym 1984.

Jan Paweł II, Encyklika Redemptoris missio. O stałej aktualności postania misyjnego, Rzym 1990.

Jan Paweł II, Katechezy: Wierzę w Ducha Świętego Pana i Ożywiciela, Vatican 1992.

Jan Paweł II, Encyklika Veritatis splendor, Rzym 1993.

Jan Paweł II, List apostolski Tertio millennio adveniente w zwiazku z przygotowaniem Jubileuszu Roku 2000, Watykan 1994.

Jan Paweł II, Encyklika Ut unum sint, O działalności ekumenicznej, Rzym 1995. 
Paweł VI, Encyklika Evangelii nuntiandi, Rzym 1975.

Paweł VI, Konstytucja apostolska Divinae consortium naturae, AAS 63/1971, s. 657-664.

\section{Literatura źródłowa}

Bartoszek J., Chromy R., Piechaczek K. (red.), Jesteśmy napetnieni Duchem Świętym. Program duszpasterski Kościoła w Polsce na rok 2017/2018. Zeszyt teologiczno-pastoralny, Katowice 2017.

Bartoszek J., Chromy R., Piechaczek K. (red.), W mocy Bożego Ducha. Program duszpasterski Kościoła w Polsce na rok 2018/2019. Zeszyt teologiczno-pastoralny, Katowice 2018.

\section{Literatura przedmiotu}

Adamczewski B., Czy Jan byt czwartym synoptykiem? Warszawskie Studia Teologiczne 31(2018) nr 1, s. 79-93.

Adamczewski B., Kościót jako ikona Ciała Chrystusa w Pierwszym Liście do Koryntian, Verbum Vitae 6/2004, s. 147-168.

Alsac J.-B., Laska chrztu w Duchu Świętym, tłum. M. Szewc-Osiecka, Kraków 2018.

Atanazy Aleksandryjski, Epistula ad Serapionem 1,19. Epistula Ad Serapionem 11,24, PG 26,586.

Balter L., Duch Święty w tajemnicy Maryi i Kościoła, w: J.S. Gajek, K. Pek (red.), Matka Jezusa pośród pielgrzymującego Kościoła, Theotokos 4, Warszawa 1993, s. 243-257.

Balter L., Pneumahagijny wymiar tajemnicy zbawienia, Ateneum Kapłańskie 96/1981, s. 182-193.

Bartnik Cz., S., Dogmatyka katolicka, t. I, Lublin 1999.

Bartosik G. M., Mediatrix in Spiritu Mediatore. Pośrednictwo Najświętszej Maryi Panny jako uczestnictwo w pośredniczacej funkcji Ducha Świętego $w$ świetle teologii wspótczesnej, Seria Biblioteka Mariologiczna 5, Niepokalanów 2006.

Bolewski J., Nadzieja jedności w Duchu Świętym, w: tenże (red.), Znaki nadziei trzeciego tysiaclecia, Kraków 1999, s. 143-166.

Brusiło J., Duszpasterskie aspekty przyjęcia darów Ducha Świętego, w: Bartoszek J., Chromy R., Piechaczek K. (red.), Jesteśmy napetnieni Duchem Świętym. Program duszpasterski Kościoła w Polsce na rok 2017/2018. Zeszyt teologiczno-pastoralny, Katowice 2017, s. 99-111. 
Buczek J., Pneumatologia sakramentalna w nauczaniu Jana Pawła II, Resovia Sacra. Resovia Sacra. Studia Teologiczno-Filozoficzne Diecezji Rzeszowskiej 13/2006, s. 49-77.

Chrostowski W., Biblijna nauka o Duchu Świętym, w: Bartoszek J., Chromy R., Piechaczek K. (red.), Jesteśmy napełnieni Duchem Świętym. Program duszpasterski Kościoła w Polsce na rok 2017/2018. Zeszyt teologiczno-pastoralny, Katowice 2017, s. 45-58.

Congar Y., Wierzę w Ducha Świętego, t. I, Warszawa 1997.

Congar Y., Wierzę w Ducha Świętego, t. II, Warszawa 1995.

Congar ., Wierzę w Ducha Świętego, t. III, Warszawa 1996.

Czaja A., Kościól jako komunia w Duchu Świętym. Koncepcja Józefa Kardynała Ratzingera, w: J. Cichoń (red.), Ratio et revelatio. Z refleksji filozoficzno-teologicznych, Opole 1998, s. 351-368.

Czaja A., Od przyjęcia darów Ducha Świętego do apostolatu i misji. Wielkie możliwości i zadania, w: Bartoszek J., Chromy R., Piechaczek K. (red.), W mocy Bożego Ducha. Program duszpasterski Kościoła w Polsce na rok 2018/2019. Zeszyt teologiczno-pastoralny, Katowice 2018, s. 49-64.

Czaja A., Problem pentekostalizacji chrześcijaństwa, Referat wygłoszony na Jasnej Górze 24 stycznia 2017 roku, podczas XXVI Sympozjum dla księży rekolekcjonistów, ojców duchownych i spowiedników kapłańskich, http://formacja. diecezja.tarnow.pl/2017/09/ problem -pentekostalizacji-chrzescijanstwa-bp-andrzej-czaja/.

Duch, który umacnia miłość. Siedem darów Ducha Świętego, Wyd. „M”, Kraków 2017.

Fic L., Dialog międzyreligijny, Pedagogia Christiana 26(2010) nr 2, s. 51-64.

Góźdź K., Kościól zbawienia, Lublin 2010.

Hryniewicz W., Człowiek w mocy Ducha Świętego. Zarys pneumatologii Ojców Wschodnich, Znak 29(1977) nr 7-8, s. 775-793.

Hurley M., Christian unity. An ecumenical second spring? Dublin 1998.

Kantyka P., Dialog ekumeniczny, w: M. Rusecki (red.), Chrześcijaństwo $w$ dialogu, Studia Nauk Teologicznych PAN, t. 5, wyd. KUL, Lublin 2010, s. 187-198.

Kiciński J., Charyzmaty odnawiaja Kościót - perspektywy i zagrożenia, w: Bartoszek J., Chromy R., Piechaczek K. (red.), Jesteśmy napetnieni Duchem Świętym. Program duszpasterski Kościoła w Polsce na rok 2017/2018. Zeszyt teologiczno-pastoralny, Katowice 2017, s. 83-98.

Kleineidam F., Dynamische Pneumatologie und Christentum: Heiliger Geist im 21. Jahrhundert, Fischer, Frankfurt am Main 2009. 
Kobyliński A., Etyczne aspekty stosowania psychologii w przestrzeni życia religijnego, Rocznik Teologii Katolickiej 14(2015) nr 1, s. 193-211.

Kobyliński A., Etyczne aspekty współczesnej pentekostalizacji chrześcijaństwa, https://www.deon.pl/religia/wiara-i-spoleczenstwo/art,1428, etyczne-aspekty-wspolczesnej-pentekostalizacji-chrzescijanstwa.html.

Kowalczyk M., Charyzmat, w: M. Rusecki i in. (red.), Leksykon Teologii Fundamentalnej, wyd. TN KUL - Wyd. „M”, Lublin-Kraków 2002, s. 184-188.

Kowalczyk M., Poczęcie Chrystusa ,przez wiarę”, Salvatoris Mater 2(2000) nr 2, 105-114.

Kowalczyk M., Ruchy kościelnej odnowy w ocenie biskupa Josefa Cordesa, Collectanea Theologica 70(2000) nr 3, s. 205-211.

Malina A., Stowo, które przekonuje (1Tes 1,5). Biblia o mocnych w Duchu Świętym i ich dziełach, w: Bartoszek J., Chromy R., Piechaczek K. (red.), W mocy Bożego Ducha. Program duszpasterski Kościoła w Polsce na rok 2018/2019. Zeszyt teologiczno-pastoralny, Katowice 2018, s. 35-47.

Nadolski B., Duch Święty w liturgii, Communio 8(1988) nr 1, s. 104-113.

Piechaczek K., Założenia, cele, tematyka Programu duszpasterskiego na lata 2017-2019 „,Duch, który działa przez miłość”, w: Bartoszek J., Chromy R., Piechaczek K. (red.), Jesteśmy napetnieni Duchem Świętym. Program duszpasterski Kościoła w Polsce na rok 2017/2018. Zeszyt teologiczno-pastoralny, Katowice 2017, s. 13-19.

Ratzinger J. / Benedykt XVI, Opera Omnia, t. X: Zmartwychwstanie i życie wieczne. Studia o eschatologii i nadziei, wyd. KUL, Lublin 2014.

Ratzinger J. / Benedykt XVI, Opera Omnia, t. VI, cz. 1: Jezus z Nazaretu. Studia o chrystologii, wyd. KUL, Lublin 2015.

Ratzinger J. / Benedykt XVI, Opera Omnia, t. VI, cz. 2: Jezus z Nazaretu. Studia o chrystologii, wyd. KUL, Lublin 2015.

Schulz A., Duch Święty animatorem apostolstwa świeckich, w: Bartoszek J., Chromy R., Piechaczek K. (red.), W mocy Bożego Ducha. Program duszpasterski Kościoła w Polsce na rok 2018/2019. Zeszyt teologiczno-pastoralny, Katowice 2018, s. 105-122.

Siemieniewski A., Kiwka M., Boży płomień. Chrzest w Duchu Świętym, wyd. Wrocławskiej Księgarni Archidiecezjalnej, Wrocław 2017.

Stasiak S., Duch w Liście do Rzymian, Studia Gdańskie 43/2018, s. 62-76.

Śmigiel W., Teologia sakramentu bierzmowania, w: Bartoszek J., Chromy R., Piechaczek K. (red.), Jesteśmy napetnieni Duchem Świętym. Program duszpasterski Kościoła w Polsce na rok 2017/2018. Zeszyt teologiczno-pastoralny, Katowice 2017, s. 59-81. 
Warzeszak J., Duch Święty a grzech. Przyczynek do hamartiologii pneumatologicznej, WST 22(2009) nr 2, s. 151-190.

Wołyniec W., Duch Święty i Kościól w petni objawienia, Wrocław 2008.

Zimoń D., Odnowiona liturgia sakramentu bierzmowania, Śląskie Studia Historyczno-Teologiczne 8/1975, s. 285-292. 